\title{
History Rewritten in a Postmodern Novel: Opposed Views on History in Jeanette Winterson's The Passion
}

\author{
Hatice Eşberk \\ Department of English Language and Literature, Erciyes University, 38039, Kayseri, Turkey \\ E-mail: hemre@erciyes.edu.tr
}

Received: 19-12- 2014

Published: 01-07- 2015
Accepted: 26-02- 2015

doi:10.7575/aiac.ijalel.v.4n.4p.268
Advance Access Published: February 2015

URL: http://dx.doi.org/10.7575/aiac.ijalel.v.4n.4p.268

\begin{abstract}
The relationship and interaction between literature and history has long been analyzed and discussed throughout the history of literature. In twentieth century literature this relationship has shown itself within the works of historiographic metafiction. In this kind of writing, previously held notions about language, truth, history and literature are subverted. With the rise of postmodern theories, such as poststructuralism, these concepts are thought of carrying no more definite, full and total meaning and reference. Winterson's The Passion is one of the best examples of historiographic metafictions that underline the polyphonic structure lying beneath systems of meaning. In The Passion Winterson's handling of the subject is surrounded by her use of multiple narratives, parody and fantasy. Thus, this paper aims at presenting how these ingredients of historiographic metafiction display themselves in Winterson's The Passion.
\end{abstract}

Keywords: historiographic metafiction, Winterson, postmodern idea of history

\section{Introduction}

Postmodern theory suggests a different view of history from that of the nineteenth century. According to this kind of consideration of history, the relationship between history and fiction is a blurring one. What lies beneath this change can be taken as the changed view of language. By the poststructuralists' arguments that result in the split between the signifier and the signified, language becomes no longer carrying a full and total meaning. When it is applied to the field of history and when Lyotard's idea of legitimization of truth is considered, it is seen that what is taken to be as 'historical truth' is subverted by this new turn. Lyotard defines that his questioning of legitimatization lies under his quest in the question of the status of knowledge (qtd. in Bennington and Massumi, 1984, p.6). Thus, availability of objective truth free from any subjective argument is questioned.

This new tendency has shown itself in postmodern literary works which results in the creation of historiographic metafiction. The Passion by Jeanette Winterson is one of the best examples of historiographic metafictions which reflect the relationship between fiction and history in an original way. In The Passion Winterson's handling of the subject is surrounded by her use of multiple narratives, parody and fantasy. Thus, this paper aims at presenting how these ingredients of historiographic metafiction display themselves in Winterson's The Passion.

\section{Historiographic Metafiction and Its Premises}

The rise of the postmodern historiographic metafiction has its roots in the changing view of both the concept of history and the concept of writing (fiction). As Hutcheon claims both history and fiction are discourses that constitute systems of "signification by which we make sense of the past. In other words, the meaning and shape are not in the events, but in the systems which make those past 'events' into present historical 'facts"' $(1988, \mathrm{p}$. 89). Thus, history and fiction are seen as systems of constructions which reflect subjective point of view. What is also emphasized in Hutcheon's analysis is that in postmodern era the meaning underlying 'the historical' and 'the fictional' has gained another dimension. According to this perspective meaning, in general, is constructed within an already existent system.

Therefore, a sceptical view of these concepts arises and the idea that "...there can be no single, essentialized, transcendent concept of "genuine historicity" is widely accepted. (Hutcheon, 1988, p. 89). This kind of understanding of history is the result of the belief that is quoted by Hutcheon from Kermode: "we can, indeed, no longer assume that we have the capacity to make value-free statements about history" (qtd. in Hutcheon, 1988, p. 90). Thus, in addition to the constructed nature of history, the subjectivity in its interpretation is emphasized. The reason of this new perception of history is summarized by Huctheon's quote as follows:

The new history we are beginning to see these days has little in common with the old-and for an interesting historical reason: its practitioners were nurtured in the theoretical climate of the 1970s, a time during which the individual literary work came to lose its organic unity; when literature as an organized body of knowledge abandoned the boundaries that had hitherto enclosed it, to an extent even abandoned its claim to knowledge; and when history began to seem discontinuous, sometimes in fact no more than just another fiction. It is no wonder that the scholarship we now pursue cannot take form or speak the language of the older literary history (1988, p.91). 
Therefore, the close relationship between history and fiction is emphasized and even it is claimed that history is nothing different from fiction. The refusal of postmodern theory of the absolute knowledge and truth inevitably gives way to the disconnectedness and the fictitiousness of history. By means of combining these ideas in its premise "[h]istoriographic metafiction refutes the natural or common-sense methods of distinguishing between historical fact and fiction. It refuses the view that history has a truth claim" (Hutcheon, 1988, p. 93). The critic adds that "both history and fiction are discourses; human constructs, signifying systems, and both derive their major claim to truth from that identity" (1988, p.93).

As a result, the quality of historiographic metafiction finds its way in its rejection of absolute knowledge and truth about history and fiction. With this belief, this kind of writing claims and puts emphasis on the subjective attitude of both terms. The seperation of history and fiction is also rejected and the combination of them is seen as the right handling of these concepts. They are both considered as discourses surrounded by a subjective systematic construction. Hutcheon summarizes the starting point and progress of this kind of writing as follows:

In the nineteenth century literature and history were considered branches of the same tree of learning, a tree which sought to interpret experience, for the purpose of guiding an elevating man. Then came the seperation that resulted in the distinct disciplines of literary and studies today...it is this very seperation of the literary and historical that is now being challenged in postmodern theory and art, and recent critical readings of both history and fiction have focused more on what the two modes of writing share than on how they differ. They have both been seen to derive their force more from verisimilitude than from any objective truth; they are both identified as linguistic constructs, highly conventionalized in their narrative forms, and not at all transparent either in terms of language or structure...deploying the texts of the past within their own complex textuality (1988, p. $105)$.

Therefore, historiographic metafiction has an understanding of history and fiction as a combination. This combination has its own standpoints such as the complex linguistic construction of the historical and the fictional, the subjective nature of this construct and the relative approach to truth and knowledge. Hence the history is re-constructed and rewritten in historiographic metafiction. As Hutcheon states, "[p]ostmodern fiction suggests that to re-write or to represent the past in fiction and in history is, in both cases, to open it up to the present, to prevent it from being conclusive (1988, p. 106).

\section{The Passion as Historiographic Metafiction}

In this novel, Winterson relies on a historical period for the infrastructure of her work, the Napoleonic period. However, this reliance does not have an aim to provide a sequential listing of the historical events of that time. Unlike of this, the writer aims to re-construct that historical period in order to display the questionable objectivity of the history. "Her fiction frequently calls into question assumptions about narratorial identity, fictional artifice, and objective reality" (qtd. in Grice\&Woods, 1998, p. 1). In order to present the history as a subjective construct she uses multiple narratives, Henri's and Vilanelle's, in the novel.

The Passion contains many realities. In one sense...it is Winterson's epic...The novel uses the memories of its characters to bring the past to life, turning The Passion into a strict (and free) piece of historical fiction. Winterson emphasizes therefore, the inconsistencies of these memories to show that rational, sequential, eventdriven history is at root just as illogical in its granting primacy to certain features of the past as are contemporary rereadings of history (Pressler, 1997, p. 13).

As it is emphasized here, to utilize the memories of characters in revealing historical events is an attempt to underline the subjectivity beneath history. Moreover, the use of parody on religious and social constructs and the fantastic nature of the novel reinforce the writer's aim in creating such a novel which reflects the implications of historiographic metafiction.

The beginning of the novel narrated by Henri, which is "[i]t was Napoleon who had such a passion for chicken that he kept chiefs working around the clock" (Winterson, 1997, p.1), foreshadows what kind of understanding of history is going to be presented in the novel. It begins neither with a particular historical event nor with biographical information about Napoleon. The passion of Napoleon is given first, thus, the emphasis on the subjectivity of history is at work at the beginning. The first narrator, Henri, goes on to tell that period by means of underlying the feelings and emotions. He tells how Napoleon likes the horses and how the soldiers feel excessive devotion to Napoleon. Moreover, Henri's definiton of that period shows the nature of his telling on history. He says,

Nowadays people talk about the things he did as to they made sense. As to even his most disastrous mistakes were only the result of bad luck or hubris. It was a mess. Words like devastation, rape, slaughter, carnage, starvation are lock and key words to keep the pain at bay. Words about war that are easy on the eye. I'm telling you stories. Trust me (Winterson, 1997, p.5).

In this statement Henri underlines that the expected words about the war would be 'devastation, rape, slaughter, carnage, starvation'. However, he makes emphasis on the questionability of such kind of reflection of history in his 
words by stating that he is telling us stories and he must be trusted. Therefore, Winterson expresses the idea that the fictionality in history is the one and only way of considering it by Henri's words.

Moreover, although Henri serves in Napoleon's army he does not tell about the historical events in detail. Instead of this, he describes Napoleon's passion for chickens, how it is like to kill the chickens for him and how he is treated by the leader and the cook. As Pressler declares,

Even though Winterson's character Henri serves in Napoleon's army for eight years, he provides us with precious little in the way of typical historical detail. Instead he discusses at great length Napoleon's passion for chicken. Henri describes twice in the novel how the cook keeps the parsley for garnishing the poultry in a dead man's helmet. These artifacts from the past are important to Henri and establish the importance therefore seemingly irrelevant detail in recreating the past in its entirety: its feel, its textures, its tastes, its smells (1997, p.16).

These things about the past are much more important than the events themselves for Henri. When he decides to write a diary, he emphasizes this idea by telling that "I don't care about the facts Domino, I care about how I feel. How I feel will change, I want to remember that" (Winterson, 1997, p.29). After he reads his diary he confesses that his devotion for Napoleon's words is not a definite one. He says, “I only later realized how bizarre most of [Napoleon's aphorisms] were" (Winterson, 1997, p.30). Thus, his writing makes his idea change in time. As Hutcheon states about that feature of the postmodern novel, "history and fiction are themselves historical terms and their definitions and interrelations are historically determined and vary with time" (1988, p.105).

Therefore, Henri's diary stands in contrast with the reflections of a traditional historian. He states "I invented Bonaparte as much as he invented himself" (Winterson, 1997, p. 158). In this statement the validity of historical view that fiction and history are seperable is problematized and the combination of these concepts is underscored. In presenting such a view Winterson underlines that she subverts and re-constitutes history in the novel. Moreover, she tries to make the reader to pay attention to the subjectivity of history. It is Henri's construction of the past; subjective which is full of emotions rather than the recounting of historical events. As Hutcheon states "historiographic metafictions privilige multiple points of view... This is not a transcending of history, but a problematized inscribing of subjectivity into history" (Winterson, 1997, p.117).

As for Vilanelle, she is herself a subversion of the traditional belief system. She works in a casino, she wears like a boy and she likes gambling. She is like the city in which she lives in, Venice. Like the fluidity of the city, Vilanelle's life is on the slippery ground. She lives for her passion. Her passion for gambling is the result of her playful nature. She says, "I dressed as a boy because that's what the visitors like to see. It was part of the game" (Winterson, 1997, p.54). Unlike Henri's devotion to Bonaparte, Vilanelle constructs different history from him. This difference is obvious in her statement that "It was August. Bonaparte's birthday and a hot night. We were due for celebration ball in the Piazza San Marcoi though what we Venetians had to celebrate was not clear" (Winterson, 1997, p.54). Moreover, Vilanelle puts more emphasis on the present, unlike of Henri, she says, "all time is eternally present and so all time is ours" (Winterson, 1997, p.62).

Thus, Winterson provides the quality of the historiographic metafiction in her novel by presenting two different points of view about the same historical period. In addition to what is written in history books about the Napoleonic era, the two fictional characters', Vilanelle's and Henri's, view on the same period are presented. Henri reconstructs the historical events in his journal. Vilanelle, by providing different perspective from that of Henri's, reconstructs the already reconstructed history. Henri views the past differently, Vilanelle sees it differently. As Bengston suggests, "Vilanelle and Henri narrate very differently: Vilanelle is poetry (hence her name) and in a sense Henri's muse; Henri the writer who grapples with the natures of passion and obsession as illustrated in his progress from an immature worship of Napoleon to an adult, selfless love for Vilanelle" (1999, p.24). They both construct their own pasts in their narratives. Winterson reconstructs history in this way in the novel. According to Arostegui,

The Passion reveals a polyphonic narrative structure that merges two apparently opposed narrative modes, the historical and the fantastic. Henri, a narrator and author of a war journal that he rewrites into his memoirs, illegitimizes history as a grand narrative and shows instead that history, like the past, is always subject to manipulation. Henri's historical discourse propounds the collapse of the holding values of patriarchy and provides the necessary space for the development of Vilanelle's alternative discourse. Vilanelle [...] exposes the fairy tale as an ideologically laden literary genre based on sexual categories and patriarchal structures $(2000$, p.17).

Henri's and Vilanelle's views of history and of the historical events signify their own qualities as characters. Although Henri has a critical view of the events of the past, his narration has the impacts of what he has been taught before. He thinks "soldiering is a fine life for a boy" (Winterson, 1997, p. 8), he is grateful to his mother and the priest for their efforts, "[ $t$ ] hanks to my mother's efforts and the rusty scholarliness of our priest I learned to read in my own language, Latin and English and I learned arithmetic, the rudiments of first aid" (Winterson, 1997, p.12). However, as he goes on to write about the past events, he also reveals the paradoxes between what he has been taught before and what he feels. He says, "[t]hey say the dead don't talk. Silent as the grave they say. It's not true. The dead are talking all the time. On 
this rock, when the wind is up, I can hear them. I can hear Bonaparte; he didn't last long on his rock” (Winterson, 1997, p. 133).

On the other hand Vilanelle's narration is much more critical and fantastic as much as it is critical. She notes,

Our ancestors. Our belonging. The future is foretold from the past and the future is only possible because of the past. Without past and future, the present is partial. All time is eternally present and so all time is ours. There is no sense in forgetting and every sense in dreaming. Thus the present is made rich. Thus the present is made whole. On the lagoon this morning, with the past at my elbow, rowing beside me, I see the future glittering on the water. I catch sight of myself in the water and see in the distortions of my face what I might become. If I find her, how will my future be? I will find her (Winterson, 1997, p. 62)

What she narrates about the effects of war reflects her dream-like interpretations of the past.

Watching my comrades die was not the worst thing about that war, it was watching them live. I had heard stories abot the human body and the human mind, the conditions it can adapt to, the ways it chooses to survive... When there's no food it [the body of human] turns cannibal and devours its fat, then its muscle then its bones. I've seen soldiers, mad with hunger and cold, chop off their own arms and cook themhow long could you go on chopping? Both arms. Both legs. Ears. Slices from the trunk. You could chop yourself down to the very end and leave the heart to beat in its ransacked palace" (Winterson, 1997, p. 82).

In addition to this multiple narrations, Winterson uses fantastic images such as Vilanelle's webbed feet, walking on the water, Vilanelle's stolen heart and Patrick's telescopic eye, in order to reconstruct the perception of history. Thus, fantastic elements are used to emphasize the fictionality and self-referentiality of the text. Since the story reflects a particular historical period, the uses of fantastic elements reinforce the questionability of the existence of the absolute truth and knowledge about the historical facts. As Waugh reflects, "[t]he essence of the fantastic...is that it 'hesitates' both understanding and definition of the 'reality' outside the fiction. All metafictional texts question precisely this 'existence of an irreducible opposition between real and unreal'" (1984, p.109). Thus, Winterson's text, as one of the best examples of the metafictional texts, underlines the relationship between history and fiction by utilizing the premise of the 'fantastic' which points to the hesitation in the concept of reality. As Burns states, for Winterson "fantasy...is the source of belief and often the bread of survival" (1996, p.286). Moreover, the critic emphasizes "Winterson's fantasy is not simple escapism...it can help subalterns form a positive identity in the face of negative of constricitve social stereotypes" (1996, p.289). Therefore, the function of fantasy to 'hesitate', to subvert and deconstruct well fits with the nature of historiographic metafiction. In The Passion the use of fantasy with such an aim leads the reader to re-consider the 'reality and reliability' of history.

The last quality which makes the novel labelled as historiographic metafiction can be taken as its use of parody. As stated above, the nature of historiographic metafiction requires subversion, reconstruction and deconstruction. Thus, the integration of the parody becomes inevitable in such a novel. As Hutcheon states "historiographic metafictions use parody" (1988, p.129).

First of all Vilanelle's character can be taken as a parody of an understanding of socially accepted women role in society. She is a free, boy-like and passionate woman and these qualities are far from commonly accepted women role. Therefore, Vilanelle's such portrayal can be taken as a parody of social norms concerning women. Moreover, Henri's taking Vilanelle's heart can be taken as a parody of chivalric romances. In chivalric romances it is expected that the hero (Henri) will have the passion of his lover as a reward. However, this is not available for Henri, unlike of this, he becomes mad and is left rewardless.

\section{Conclusion}

In The Passion, Winterson questions the conventional understanding of history and fiction. As a postmodern novel The Passion challenges the assumptions of not only historiography but also the novel form, thus, the novel is the reflection of historiographic metafiction. Rather than providing the historical events, unnecessary (as commonly thought) details are presented by means of the first narrator to emphasize the subjectivity. Moreover, Henri's diary is the metafictional aspect in the novel which helps him to change his views on past. This is another feature of historiographic metafiction which is to combine fiction and history. The function of the second narrator, Vilanelle, is much more to do with the use of fantasy and parody in the novel. She is supernatural, passionate and free. Therefore, the novel is one of the best examples of historiographic metafiction combining different elements in it. As Palmer states Winterson enjoys, "putting new wine in old bottles-especially if the pressure of the new wine makes the old bottles explode" (qtd. in Dowson\&Earnshaw 199).

In the light of these, it would be true to claim that the novel reinforces the questioning and subverting the position of knowledge in general. What is claimed to be true knowledge carried by both a creation of literature (novel) and a creation of history is made upside down. This investigation of Winterson is a reflection of Lyotard's claim that, "[p]ostmodern knowledge is not simply a tool of the authorities: it refines our sensitivity to differences and reinforces our ability to tolerate the incommensurable" (Lyotard, 1984, p.xxv). 


\section{References}

Aróstegui, Maria Del Mar A. (2000). History as Discourse in Jeanette Winterson's The Passion: The Politics of Alterity. Journal of English Studies, 2, 7-18.

Bengston, Helena et al. (Eds). (1999). Sponsored by Demons: The Art of Jeanette Winterson. Denmark: Scholars' P.

Burns, Christy L. (1996). Fantastic Language: Jeanette Winterson's Recovery of the Postmodern World. Contemporary Literature, 37(2), 287-306.

Dowson, Jane and Steven Earnshaw. (Eds). (1995). Postmodern Subjects/Postmodern Texts. Amsterdam: Rodopi B.V.

Grice, Helena and Tim Woods. (Eds.). (1998). I'm telling you stories': Jeanette Winterson and the Politics of Reading. Amsterdam: Rodopi B.V.

Hutcheon, Linda. (1988). A Poetics of Postmodernism: History, Theory, Fiction. London: Cambridge UP.

Lyotard, J. F. (1984). The Postmodern Condition: A Report on Knowledge. Bennington, G. and Brian Massumi (trans.) Manchester: Manchester UP.

Palmer, Paulina. (1995). Postmodern Trends in Contemporary Fiction. in Postmodern Subjects/Postmodern Texts. eds. Dowson and Earnshaw..Amsterdam: Rodopi B.V.

Pressler, Christopher. (1997). So Far So Linear: Responses to the Work of Jeanette Winterson. Nottingham: Paupers' P. Waugh, Patricia. (1984). Metafiction: The Theory and Practice of Self-Conscious Fiction. London: Methuen.

Winterson, J. (1997). The Passion. New York: Grove P. 